\title{
Adrian Skoczylas
}

\author{
Uniwersytet Łódzki
}

\section{Żart skuteczniejszy od obietnic. Satyryczna kampania Najlepszej Partii i jej wyborcze zwycięstwo w Reykjaviku.}

W maju 2010 roku sukces w wyborach do Rady Miejskiej w Reykjaviku osiagnęła Besti Flokkurinn (isl. Najlepsza Partia). Rezultat elekcji zaskoczył politycznych obserwatorów - zwycięska partia deklarowała bowiem niespełnienie obietnic wyborczych, traktując kampanię wyborcza jako żart. Co trzeci głosujacy mieszkaniec stolicy Islandii chciał, aby burmistrzem jego miasta został komik, Jón Gnarr. Cała sytuację potraktowano raczej jako wybryk i sposób na głos protestu obywateli i obywatelek pogrążonego w kryzysie państwa. Najlepsza Partia jest jednak jednym z popularniejszych współczesnych przykładów szerszej grupy tzw. joke parties, niewpisujacej się w standardowe typologie partii politycznych'1.

Partie, określane jako ,joke parties", swoją działalność polityczną rozwijaja głównie w okresie wyborów, lecz ich celem nie jest zwycięstwo w nich, a w wielu przypadkach nawet nie osiagnięcie dobrego wyniku wyborczego. Główną motywacja wystartowania w wyborach jest zakpienie z polityki, zażartowanie z partii politycznych i satyra ich postulatów. Analizujac zaistniałe we współczesnym świecie przypadki tzw. joke parties, można wyróżnić następujące wspólne ich cechy:

1. otwarta deklaracja o satyrycznym i żartobliwym charakterze organizacj;;

2. nienastawianie się na maksymalizacje wyniku wyborczego;

3. brak lub minimalna liczba działających $w$ niej profesjonalnych polityków;

4. korzystanie z narzędzi artystycznych, happeningu, performance'u;

\footnotetext{
1 Niniejszy artykuł stanowi fragment pracy licencjackiej pt. „Fenomen tzw. joke parties na przykładzie wybranych kampanii wyborczych w Polsce i na świecie”, napisanej pod kierunkiem dra H. Horbaczewskiego na Wydziale Studiów Międzynarodowych i Politologicznych Uniwersytetu Łódzkiego.
} 
5. elementy programowe pośrednio lub bezpośrednio za pomoca parodii nawiazujące do kontekstów kulturowych, społecznych i politycznych.

Joke parties, które mogą być określane również jako partie satyryczne, nie są w swej grupie jednorodne. Różnią się pod względem celu wykorzystywania żartu i satyry w kampanii wyborczej (albo mają wyłącznie wzbudzać śmiech i parodiować niedoskonała politykę, albo happening jest metodą zwrócenia uwagi na istotne problemy) oraz ze względu na stosunek do udziału w wyborach i potencjalnego zdobycia władzy (sam start w wyborach jest satysfakcjonujący i nie są podejmowane działania zwiększające poparcie lub też podkreślając humorystyczny charakter kampanii, nie wyklucza się starań o udział we władzy i odpowiedzialności za nia).

Najlepszą Partię (isl. Besti Flokkurinn, ang. Best Party) w listopadzie 2009 roku założył islandzki aktor i komik, Jón Gnarr2, znany jako autor satyrycznych audycji radiowych i programów telewizyjnych. Już od 2008 roku Islandia pograżona była w kryzysie gospodarczym, a w stolicy kraju, Reykjaviku, rządziło aż 6 burmistrzów od 2003 roku. Gnarr założył partię deklarując nowy rodzaj polityki oraz parodiowanie polityków, ich wypowiedzi oraz działań. Powodem jego wejścia do polityki była frustracja wynikająca z obserwacji życia politycznego i politycznych debat, z których niewiele wynikało, zwłaszcza w okresie kryzysu³ oraz chęć wprowadzenia humoru i radości do rywalizacji politycznej.

Pierwszym satyrycznym działaniem była sama nazwa partii. Besti Flokkurinn, czyli Najlepsza Partia ma z jednej strony przykuć uwagę wyborców, a jednocześnie, jak przekonywał Gnarr, odzwierciedla jej charakter. „Nikt nie musi obawiać się Najlepszej Partii, ponieważ jest najlepsza. Gdyby nie była, nazwalibyśmy ją Najgorszą Partią", przekonywał we właściwym sobie stylu4.

Partia zdecydowała się wziąć udział w wyborach do Rady Miasta w Reykjaviku, które odbywały się w maju 2010 roku. Jón Gnarr zaprosił na listę wyborczą artystów, dziennikarzy i satyryków. Największą popularność zdobył ich film kampa-

\footnotetext{
2 Właśc. Jon Gunnar Kristinsson.

3 "Political discourse is all dead and vapid. I've never been interested in governance or politics... l've listened to all the empty political discourse, but it's never touched me at all or moved me, until the economic collapse. Then I just felt l'd had enough of those people... I started reading the local news websites and watching the news and political talk shows - and it filled me with so much frustration... So I wanted to do something, to fuck the system. To change it around and impact it in some way." Cyt. za: D. Boyer, Simply the best: Parody and political sincerity in Iceland, [w:] American Ethnologist 2013, vol. 40 , nr 2, s. 279.

4 Icelander's Campaign Is a Joke, Until He's Elected, www.nytimes.com/2010/06/26/ world/europe/26iceland.html?_r=0, data dostępu 10.06.2013.
} 
nijny, w którym wyśpiewali swój program wyborczy, wykorzystując melodię do utworu "Simply The Best” Tiny Turner: „Chcemy miłego, czystego i fajnego miasta i „bycie ekstra” jako głównej zasady rządzenia. (...) Jesteśmy najlepsi, mamy najlepszą z partii, najlepszą dla Reykjaviku, najlepszego miasta na każdy tydzień. (...) Głosuj na nas, bo jesteśmy najlepsi"5.

Program wyborczy, zwany „Platformą Najlepszej Partii”, zawierał odniesienia do idei socjalliberalnych, demokratycznych, feministycznych i ekologicznych, choć partia nie opowiadała się jasno za którąkolwiek ideologią. 13-punktowy program obejmował między innymi:

1. Pomoc gospodarstwom domowym w całym kraju. Rodzina jest najlepszą rzeczą w społeczeństwie. Rząd musi zmierzyć się z ich potrzebami i żądaniami. Trzeba postawić „żelazną tarczę ochronna” wokół gospodarstw domowych. Zasługują one na wszystko, co najlepsze.

2. Należy poprawić jakość życia osób z gorszą sytuacją życiowa. Chcemy dla nich wszystkiego najlepszego, dlatego oferujemy darmowe korzystanie z autobusów i miejskich basenów, aby można było podróżować po Reykjaviku i pozostać czystym, nawet jeśli jest się biednym albo z kimś jest coś nie tak.

3. Stop korupcji: obiecujemy zatrzymać korupcję. Zrealizujemy to poprzez otwarte uczestnictwo w niej.

4. Równość: każdy zasługuje na wszystko, co najlepsze, niezależnie od tego kim jest i skąd pochodzi. Zrobimy co w naszej mocy dla każdego tak, aby każdy mógł być razem z nami w najlepszej grupie.

5. Wzrost transparentności: najlepiej jest działać uczciwie, a wtedy opinia publiczna wie, co się dzieje. Jak mówimy, popieramy to.

6. Skuteczna demokracja! Demokracja jest naprawdę dobra, ale efektywna demokracja jest najlepsza. Dlatego też jej chcemy.

7. Zlikwidować wszystkie długi. Słuchamy narodu i robimy to, co sobie życzy, ponieważ naród wie, co jest dla niego najlepsze.

8. Darmowe przejazdy autobusowe dla studentów i kalek. Możemy zaoferować więcej darmowych rzeczy niż jakakolwiek inna partia, ponieważ i tak nie zamierzamy tego zrobić. Możemy obiecywać co tylko chcemy, na

5 Besti Flokkurinn - The Best Video, www.youtube.com/watch?v=xxBW4mPzv6E, data dostępu 10.06.2013. 
przykład darmowe przeloty powietrzne dla kobiet albo darmowe samochody dla ludzi z terenów rolniczych. Nie ma tu dla nas różnicy.

9. Darmowe usługi dentystyczne dla dzieci i osób potrzebujących. To jest coś, czego brakuje i zdecydowanie chcemy brać udział w obiecywaniu tego.

10. Wolny wstęp na miejskie baseny dla każdego i darmowe ręczniki. To jest coś, co każdy powinien poprzeć. To obietnica wyborcza, z której jesteśmy najbardziej dumni.

11. Pozwać odpowiedzialnych za kryzys do sądu. Uznaliśmy, że musimy to tutaj zawrzeć.

12. Całkowita równość płci.

13. Trzeba bardziej słuchać kobiet i starszych ludzi. Te grupy są zdecydowanie zbyt rzadko wysłuchiwane. Każdy sądzi, że oni jedynie narzekają czy coś. Zamierzamy to zmienić6.

Wśród innych „obietnic” znalazło się sprowadzenie niedźwiedzia polarnego do stołecznego zoo (ze względu na globalne ocieplenie), zbudowanie Disneylandu w centrum Reykjaviku oraz zapewnienie wolnego od narkotyków islandzkiego parlamentu do 2020 roku. Przede wszystkim jednak Jón Gnarr i pozostali kandydaci otwarcie zapowiedzieli niespełnienie obietnic wyborczych?

Program tej partii nie zawierał wyłącznie absurdalnych postulatów, których nie można zrealizować. W większości pomysły opisane przy użyciu humorystycznych i potocznych określeń mogły stanowić element programu wyborczego. W ten sposób Najlepsza Partia chciała parodiować „poważnych polityków”, którzy formułują swoje postulaty w patetyczny sposób, niejednokrotnie składając obietnice bez pokrycia.

Choć notowania Besti Flokkurinn przed wyborami były optymistyczne ${ }^{8}$, to rzeczywisty ich wynik był zaskoczeniem nawet dla samego Gnarra. W wyborach, które odbyły się 29 maja 2010 roku, Najlepsza Partia zdobyła 34,7\% (20,6 tys. głosów), zajmując pierwsze miejsce. Poparcie pozwoliło uzyskać jej 6 mandatów

\footnotetext{
6 „Platforma Najlepszej Partii”, www.bestiflokkurinn.is/um-flokkinn/stefnumal, data dostępu 10.06.2013. 7 Jon Gnarr creates a political party, www.visir.is/article/20091116/LIFID01/485732613/-1, data dostępu 10.06.2013.

$8 \quad 23,4 \%$ pod koniec kwietnia i 35,7\% 10 maja. Dane na podstawie: www.mbl.is/frettir/innlent/2010/05/17/besti_flokkurinn_staerstur_i_reykjavik, data dostępu 10.06.2013.
} 
w 15-osobowej Radzie Miasta9 ${ }^{9}$ Jon Gnarr zapowiedział, że będzie ubiegać się o stanowisko burmistrza Reykjaviku. Do tego potrzebna mu jednak była większość w Radzie i koalicja z innym ugrupowaniem. Gnarr zapowiedział, że wejdzie w koalicję tylko z tymi politykami, którzy tak jak on są fanami serialu „The Wire” (pol. „Prawo ulicy") ${ }^{10}$. Ostatecznie porozumiał się z Sojuszem Socjaldemokratycznym (isl. Samfylkingin), który dysponuje w Radzie 3 mandatami.

Już jako burmistrz, Jón Gnarr założył platformę internetową „Lepszy Reykjavik"11, za pośrednictwem której mieszkańcy miasta moga zgłaszać problemy, które zauważają w swojej okolicy, proponować rozwiązania i wspólnie o nich dyskutować. Te, które zyskają największe poparcie, zostaną zrealizowane przez burmistrza. Gnarr zaangażował się także w protest wobec chińskiego rządu w związku z traktowaniem laureata pokojowej nagrody Nobla, Liu Xiaobo.

Nie zrezygnował jednak ze swoich happeningów i satyrycznych wystapień. W sierpniu 2010 roku poprowadził Paradę Równości w Reykjaviku, przebrawszy się za drag queen ${ }^{12}$. Z okazji świą Bożego Narodzenia nagrał film, w którym składał świąteczne życzenia mając na sobie maskę Dartha Vadera z „Gwiezdnych Wojen” oraz czerwoną czapkę św. Mikołaja13. Burmistrz Jón Gnarr bardzo dużo czasu spędza na portalu społecznościowym Facebook, gdzie na co dzień przekazuje informacje o swojej pracy, podróżach i poglądach politycznych ${ }^{14}$.

Najlepsza Partia nawiązała współpracę z niemiecką Partią Piratów. Jej pierwszym efektem była „Deklaracja Niczego” (ang. Declaration on Nothing), która przedstawiciele obu partii podpisali 22 listopada 2010 roku. Istotą tego "dokumentu” było de facto jego podpisanie, które nie wiazzało się z żadnymi skutkami. Był to pewnego rodzaju happening, który miał parodiować podobne wydarzenia, które często są wyłącznie pustym gestem pomimo patetycznych zapisów w swojej tre-

\footnotetext{
9 Do Rady z listy Najlepszej Partii dostali się: Jón Gnarr Kristinsson (aktor, komik, lider partii), Einar Örn Benediktsson (muzyk), Óttarr Ólafur Proppé (aktor, muzyk), Elsa Hrafnhildur Yeoman (artystka), Karl Sigurðsson (dziennikarz), Eva Einarsdóttir (menedżerka kultury).

10 He Really Did It!, www.grapevine.is/Features/ReadArticle/He-really-did-it-Jon-Gnarr-HaukurMagnusson, data dostępu 10.06.2013.

11 Zob. Www.betrireykjavik.is.

12 Reykjavik Mayor Jon Gnarr leads Gay Pride, www.icenews.is/2010/08/07/reykjavik-mayor-jon-gnarrleads-gay-pride, data dostępu 10.06.2013.

${ }^{13}$ www.dv.is/frettir/2010/12/25/jolakvedja-jons-gnarr-i-liki-darth-vader/, data dostępu 10.06.2013.

14 Zob. Www.facebook.com/pages/Jón-Gnarr/244993732224805.
} 
ści15. Jak zapisano w „Deklaracji Niczego”, warunkiem jej ważności są złożone podpisy, uściśnięcie dłoni i zrobione fotografie ${ }^{16}$.

W kwietniu 2013 roku Najlepsza Partia uzyskała status obserwatora w Międzynarodowej Organizacji Partii Piratów ${ }^{17}$.

Wyzwaniem dla partii Jóna Gnarra stała się kwestia wyborów do islandzkiego parlamentu na wiosnę 2013 roku. Choć początkowo Gnarr nie zamierzał ubiegać się o mandat posła, to jednak w grudniu 2012 oficjalnie zapowiedział, że wystartuje z list partii Jasna Przyszłość (ang. Bright Future, isl. Björt framtíð). Partia ta została założona w lutym 2012 roku, przez dwóch islandzkich deputowanych: Guðmundura Steingrímssona (wcześniej członek Partii Postępu) i Róberta Marshalla (wcześniej członek Sojuszu Socjaldemokratycznego). Jednakże formalnie połaczyła się z Najlepszą Partia, o czym świadczyć miały m.in. islandzkie inicjały „BF”. Kandydatami nowej partii w wyborach parlamentarnych byli zarówno wcześniejsi zawodowi politycy jak i członkowie Najlepszej Partii, w tym radni Reykjaviku.

Profil „Jasnej Przyszłości” w nieznacznym stopniu pozostał satyryczny. Partia promowała pozytywne usposobienie do polityki i dystans do poważnych spraw, jednak jej postulaty były całkiem poważne. Członkowie Najlepszej Partii otrzymali dość słabe miejsca na listach wyborczych - sam Jón Gnarr w stołecznym okręgu dostał dopiero 5. miejsce, które naturalnie nie dawało szans na mandat. Sam jednak przyznawał, że udziela Jasnej Przyszłości tylko „wsparcia moralnego”, jako że „nie ma w niej niczego anarchistycznego ani surrealistycznego, jest to po prostu typowa partia liberalno-demokratyczna"18.

15 Spaßreise nach Island: Die Berliner Piraten und ihr Konzept des Nichts, www.welt.de/politik/ausland/article13674728/Die-Berliner-Piraten-und-ihr-Konzept-des-Nichts.html, data dostępu 10.06.2013.

16 Pełna treść „Deklaracji Niczego": "We, the undersigned, agree to the meet and sign this declaration. The declaration does not involve anything in particular. It is not binding. A signature does not entail any sort of obligations or terms to be observed. The purpose of this declaration is solely to create an opportunity for people to meet and unite in a symbolic manner, with a signature. It is especially important that this event, when the declaration is signed, be documented with photograph. That is not a binding situation, however. We, the undersigned, would be happy if the parties that sign it could shake hands when the signing is over and even pose for photographs. If this event is not documented with a photograph, the signatures are null and void. Cyt. za: www.kosmos.welt.de/2011/10/declaration-on-nothing.

17 Best Party Integrated Into International Pirate Party, www.grapevine.is/Home/ReadArticle/Best-PartyIntegrated-Into-International-Pirate-Party, data dostępu 10.06.2013.

18 Dominic Boyer interviews Mayor of Reykjavík, www.americanethnologist.org/2013/dominic-boyerinterviews-mayor-of-reykjavik, data dostępu 10.06.2013. 
W przedwyborczych sondażach Jasna Przyszłość mogła liczyć od 4-5\% w połowie roku 2012 do nawet 16-17\% w lutym 2013. Ostatecznie w wyborach, które miały miejsce 27 kwietnia 2013 roku, zdobyła ona 8,25\% i 6 mandatów w islandzkim Parlamencie. Jedynym kandydatem związanym z Najlepszą Partia, któremu udało się wejść do Althingu, jest Óttarr Ólafur Proppé, który jednocześnie pozostał radnym Reykjaviku'19.

Jón Gnarr jest najdłużej urzędującym burmistrzem Reykjaviku od 2003 roku. Po ponad 3 latach rządzenia w Reykjaviku, Najlepsza Partia wciąż utrzymuje wysokie poparcie. Z sondażu przeprowadzonego na początku maja 2013 roku wynikało, że mogliby teraz liczyć na 32\% głosów, podobnie jak Partia Niepodległości (isl. Sjálfstæðisflokkurinn)20. To zaś mogłoby dać jej duże szanse na pozostanie przy władzy albo przynajmniej udział w pracach Rady Miejskiej w kolejnej kadencji.

Kwestia przynależności ideologicznej Najlepszej Partii jest dyskusyjna. Głównym motywem funkcjonowania jest niewatpliwie żart i satyra, niemniej w postulatach i działaniach odnaleźć można elementy lewicowe, socjaldemokratyczne czy socjalliberalne. Sama partia określa się jako „anarcho-surrealistyczna”21. Jón Gnarr na swoim Facebookowym profilu zamieścił grafikę potwierdzająca jakoby jego poglady mieściły się w ćwiartce „lewica” i „permisywizm” w dwuwymiarowej osi J. Steinera. Jakkolwiek nie może to służyć za wiarygodne potwierdzenie jego opcji politycznej, o tyle w zestawieniu z wspomnianymi wcześniej działaniami o charakterze wolnościowym i równościowym, tworzy to spójną całość, potwierdzająca przynajmniej usposobienie lidera partii.

Jednakże fenomen Jóna Gnarra politolodzy i dziennikarze zaproponowali opisać za pomoca innej kategorii, pochodzącej wprost od nazwiska burmistrza Reykjaviku. Gnarryzm (ang. gnarrism) oznaczać ma „politykę uprawianą przez ludzi przeciwnych polityce"22. W zachowaniu Gnarra potwierdza się to, jeśli spojrzeć na sposób komunikowania się z wyborcami i administrowania miastem. W jednym

19 Dane na podstawie: Icelandic parliamentary election 2013, www.en.wikipedia.org/wiki/ Icelandic_parliamentary_election,_2013, data dostępu 10.06.2013.

20 Reykjavik Mayor's Best Party with 32 Percent Support, www.icelandreview. com/icelandreview/daily_news/Reykjav\%C3\%ADk_Mayor\%E2\%80\%99s_Best_Party_with_32_Percent _Support_0_399921.news.aspx, data dostępu 10.06.2013.

21 Ang. "politics by people opposed to politics", What Are You Voting For, Reykjavík?, www.grapevine.is/Features/ReadArticle/Feature-What-Are-You-Voting-For-Reykjavik, data dostępu 10.06.2013.

22 Iceland brought in from the cold thanks to party of punks and pop stars, www.guardian.co.uk/world/2011/jun/19/iceland-reykjavik-mayor-best-party, data dostępu 10.06.2013. 
z wywiadów powiedział: „Moją strategia od samego początku było przyznawanie się, że czegoś nie wiem, a właściwie, że nie wiem nic. (...) Przeprowadzano ze mna wywiad w lokalnej telewizji i zadano mi pytanie. Odpowiedziałem szczerze, że nie wiem - mogę się dowiedzieć i dać odpowiedź później albo poprosić o to kogoś, kto ja zna. Chyba po raz pierwszy w historii świata i ludzkości polityk powiedział w telewizji, że czegoś nie wie"23.

Gnarr połączył powagę z humorem nawet przy okazji debaty nad budżetem Reykjaviku w grudniu 2011 roku, podczas której przekonywał, że jako partia zmuszeni są zmniejszyć liczbę usług i zwiększyć obciążenia, co nie jest „zabawna” sytuacją. Wyraził jednak nadzieję na solidarną współpracę z mieszkańcami dla dobra miasta. Wypowiedź zakończył apelem: „Mamy ten wspaniały kraj i możliwości, które daje. Nie musimy być smutni, możemy się śmiać, bawić się i opowiadać dowcipy. Uśmiech jest darmowy"24.

Przywódcy partii satyrycznych są połączeniem kilku typów wizerunku politycznego kandydatów na liderów starających się o poparcie i startujących w wyborach. Na przykładzie postaci takich jak Jón Gnarr czy innych podobnych jemu liderów dostrzegamy następujące typy:

1. „zwykłego człowieka”, podkreślającego brak dystansu między sobą a elektoratem i znajomość ludzkich spraw,

2. „ekscentryka”, realizującego nowe pomysły, nieprzejmującego się powszechnym odbiorem własnej osoby przy założeniu, że popularność osiąga się poprzez wyróżnianie się z tłumu,

3. „błazna”, który ośmiesza utrwalone zwyczaje i kontestuje dotychczasowy porządek,

4. „luzaka”, który okazuje swą niezależność i swobodny stosunek do poruszanych

w przestrzeni publicznej spraw25.

Należy podkreślić, że ogromną szansą dla satyrycznych partii w XXI wieku stał się Internet. Zanim stał się on najbardziej powszechnym i najszybszym kanałem dotarcia do wyborców, partie niewpisujące się w standardy rywalizacji politycznej,

23 The Comedian Mayor: The Rumpus interview with Jón Gnarr, www.therumpus.net/2012/08/thecomedian-mayor-the-rumpus-interview-with-jon-gnarr/, data dostępu 10.06.2013.

24 D. Boyer, op.cit., s. 281.

25 Zob. M. Jeziński, Wizerunek polityczny jako element strategii wyborczej, [w:] B. Dobek-Ostrowska (red.) Kampania wyborcza: marketingowe aspekty komunikowania politycznego, Wrockaw 2005, s. 115132. 
miały utrudnione zadanie, aby zaznajomić elektorat ze swoim programem i działaniami. Niewykluczone, że to właśnie Sieć, a szczególnie portale społecznościowe, znacząco pomogły odnieść zwycięstwo w wyborach w Reykjaviku partii Jóna Gnarra. Film kampanijny, w którym kandydaci śpiewali fragmenty programu wyborczego do melodii „Simply The Best” był promowany właśnie na portalach społecznościowych. Specyfika social media i dość duże zainteresowanie tamtejszych użytkowników stronami o humorystycznej treści bardzo łatwo mogłoby przerodzić się w poparcie dla partii satyrycznej, której udałoby się wykorzystać taki potencjał.

Paradoksalnie partie satyryczne dowodzą, że polityka, która ma wpływ na życie codzienne obywatela, to sprawa, którą każdy powinien traktować poważnie i z uwaga. W jednej z debat przedwyborczych w Reykjaviku Jón Gnarr powiedział: „Niektórzy uważaja, że skoro jestem komikiem, to wszystko, co robię w życiu jest pewnego rodzaju żartem. Ale to nieprawda. Jestem ojcem piątki dzieci, pochowałem ojca, miałem chore dziecko - nie byłem w tej sytuacji komikiem. Nie jestem też nim, kiedy płacę rachunki albo wychowuję swoje dzieci".

Tą wypowiedzią udowodnił, że nawet partie nastawione na żart są tworzone przez ludzi, którzy funkcjonują w określonej rzeczywistości i mają świadomość wyzwań, przed jakimi stoi ich miasto czy państwo. Być może dlatego łatwo znajduja wspólny język ze swoimi wyborcami, którzy mogą utożsamić się z „gnarryzmem”. 